\title{
Diastolic Function Assessment in Acute Coronary Syndrome
}

Ghezouani $\mathrm{H}^{*}$, Chafai Y, Benzaroual D, El Hattaoui M

Cardiology Departement; Marrakesh University Hospital Centre, Morocco

DOI: $10.36347 /$ sasjm.2020.v06i02.010

| Received: 14.02.2020 | Accepted: 21.02.2020 | Published: 25.02.2020

*Corresponding author: Ghezouani $\mathrm{H}$

\section{Abstract}

Original Research Article

Coronary artery disease is one of the main causes of morbidity and mortality in our country; it is a cardiovascular emergency that must be globally and early managed. Goals: evaluate diastolic function in acute coronary syndrome. Analyze the modifying factors of its alteration, comparing two groups' one with altered diastolic function and the other with normal diastolic function. Material and methods: Prospective descriptive analytic study on a number of 50 patients admitted for acute coronary syndrome to the cardiology department of Mohammed VI Hospital in Marrakech. Results: The age of patients is between 40 and 85 years old with an average of 62.02 years. $66 \%$ of the patients are men. $54 \%$ of patients are smokers, $46 \%$ are diabetic, $42 \%$ are obese, $26 \%$ are hypertensive and $24 \%$ have dyslipidemia. At admission $92 \%$ of patients had chest pain. At echocardiography, diastolic dysfunction was reported in $68 \%$ with elevated filling pressure of the left ventricle in $10 \%$. We found an association between diastolic dysfunction and dyslipidemia, the number of arteries with coronary angiography and the timing of the admission. Conclusion: Diastolic dysfunction was common in our population of coronary acute syndrome, hence the interest of an early echocardiographic assessment adapted to any coronary patient.

Keywords: Coronary syndrome-diastolic dysfunction-filling pressure.

Copyright @ 2020: This is an open-access article distributed under the terms of the Creative Commons Attribution license which permits unrestricted use, distribution, and reproduction in any medium for non-commercial use (NonCommercial, or CC-BY-NC) provided the original author and source are credited.

\section{INTRODUCTION}

Acute coronary syndrome is one of the main concerns of public health, due to its high morbidity and mortality [1], the management of which has become a subject of constant questioning and improvement. Echocardiography is the most common imaging technique for assessing systolic and diastolic function, which is determined by two main factors: Relaxation and compliance of the left ventricle (LV) [2]. Myocardial ischemia results in slower and incomplete ventricular relaxation [3,4], while scar tissue and myocardial fibrosis due to a previous infarction results in reduced ventricle compliance $[5,6]$. Several studies have demonstrated that the alteration in diastolic function to the question has been linked to readmission $[7,8,9,10]$, to a risk of heart failure or death after a myocardial infarction at 1 year $[11,12]$. And its assessment should be part of a routine examination of any patient admitted for acute coronary syndrome.

\section{Goals}

- Evaluate diastolic function in acute coronary syndromes.

- Analyze the predictors of impaired diastolic function, comparing two groups: one with impaired diastolic function and the other with normal diastolic function.

\section{METHODS}

This is a prospective descriptive analytical study covering a period of 6 months, from January 2017 to June 2017 , with a total of 50 patients admitted for acute coronary syndrome in the cardiology department of Mohammed VI hospital of Marrakech, within 36 hours.

\section{RESULTS \\ Epidemiological aspects}

The average age of our patients was 62.02 years (40 and 85 years), with a male predominance.

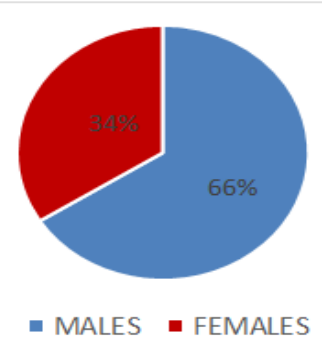

Diagram-1: Distribution of patients according to gender 


\section{Clinical aspects}

- Cardiovascular risk factors: Among cardiovascular risk factors (FDRCV), smoking and diabetes were the most represented risk factors.

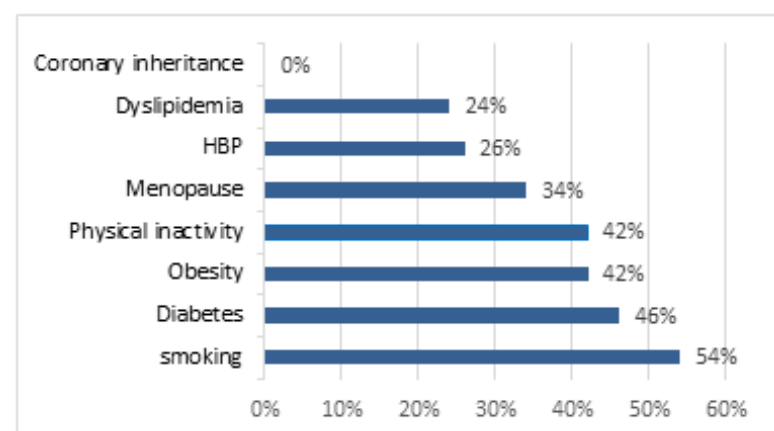

Diagram-2: Distribution of patients according to cardiovascular risk factors

- $10 \%$ of the patients were coronary.
Table-I: Distribution of patients according to their history

\begin{tabular}{|l|c|c|}
\hline \multicolumn{1}{|c|}{ background } & $\begin{array}{c}\text { Number of } \\
\text { patients }\end{array}$ & $\begin{array}{c}\text { Percentage } \\
(\mathbf{\%})\end{array}$ \\
\hline Coronary & 5 & 10 \\
\hline Vascular & 0 & 0 \\
\hline $\begin{array}{l}\text { Other than ischemic } \\
\text { heart disease }\end{array}$ & 1 & 2 \\
\hline
\end{tabular}

- Chest pain was present in $92 \%$ of patients; it was atypical in $13.04 \%$.

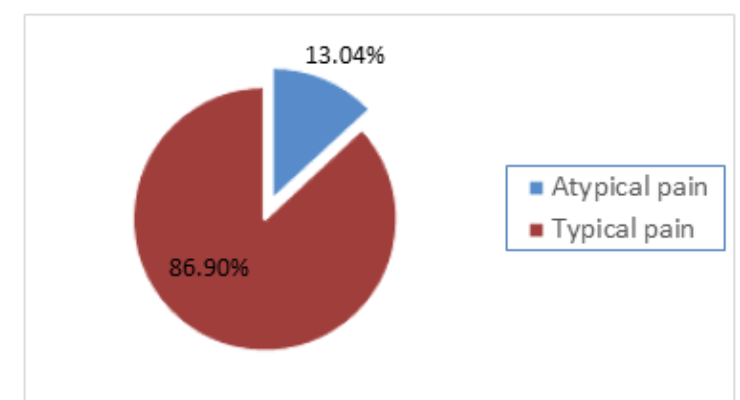

Diagram-3: Distribution of patients according to the revealing symptom

\section{- The general examination}

Table-II: Distribution according to the general examination

\begin{tabular}{|c|c|c|c|c|}
\hline & Systolic pressure & Diastolic pressure & Heart rate & Respiratory rate \\
\hline Average & 126.66 & 71.76 & 81.76 & 21.1 \\
\hline standard deviation & 17.64 & 10.55 & 21.43 & 3.83 \\
\hline Minimum & 80 & 40 & 30 & 16 \\
\hline Maximum & 170 & 90 & 130 & 35 \\
\hline
\end{tabular}

\section{Cardiovascular and pleuro-pulmonary examination}

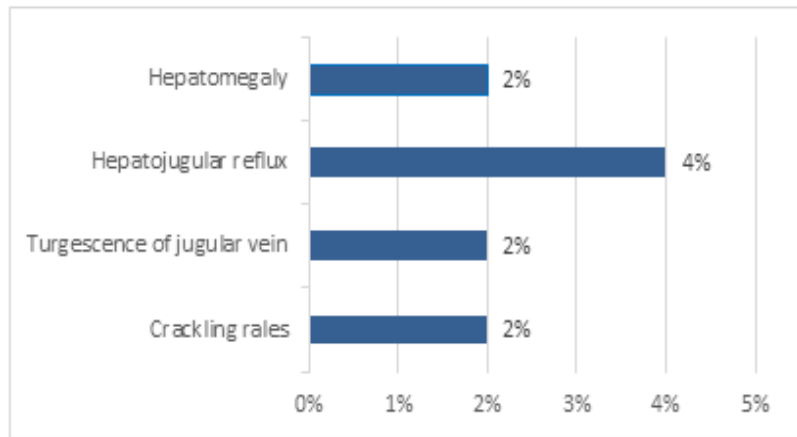

Diagram-4: Distribution according to clinical examination

\section{Paraclinical aspects}

The EKG showed: A regular sinus rhythm in $100 \%$ of the cases, an over-shift of the ST segment in $68 \%$ of the cases, an under-shift of the ST segment in $30 \%$ of the patients.

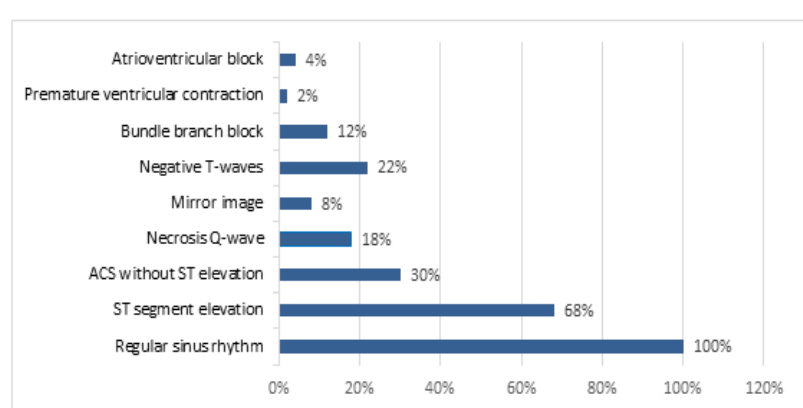

Diagram-5: Electrocardiogram abnormalities

- The topography of the electrical signs was antero-septo-apical in $42 \%$ of the cases.

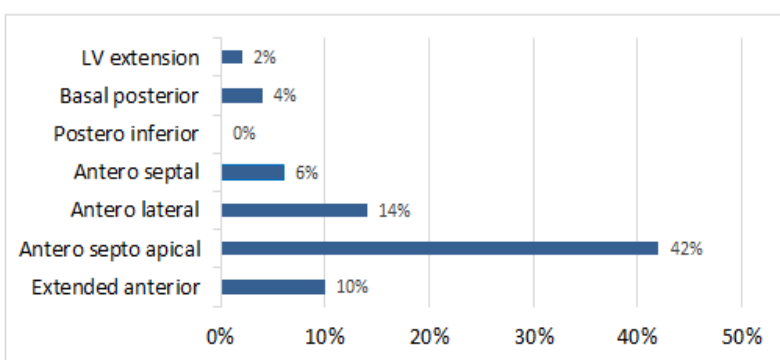

Diagram-6: Distribution according to the territory reached 
- The chest X-ray was pathological in $16 \%$ of the cases. Cardiomegaly was found in $12 \%$ of patients with an average cardio-thoracic index of 0.6 , an interstitial syndrome in $8 \%$ of patients.
- Troponins were raised in $100 \%$ of cases.

- The evaluation of diastolic function on echocardiography shows:

Table-III: Descriptive analysis of mitral flow parameters and tissue Doppler

\begin{tabular}{|c|c|}
\hline Mitral inflow and tissue Dopplerparameters & Average \\
\hline $\mathrm{E}(\mathrm{cm} / \mathrm{s})$ & 70.56 \\
$\mathrm{~A}(\mathrm{~cm} / \mathrm{s})$ & 85.18 \\
$\mathrm{E} / \mathrm{A}$ & 0.97 \\
$\mathrm{Am}(\mathrm{ms})$ & 91.30 \\
$\mathrm{E}$ & 8.8 \\
$\mathrm{E} / \mathrm{E}$ & 7.20 \\
$\mathrm{TDE}(\mathrm{ms})$ & 155 \\
$\mathrm{IVRT}(\mathrm{ms})$ & 78.87 \\
$\mathrm{OG} \mathrm{Vol}\left(\mathrm{ml} / \mathrm{m}^{2}\right)$ & 24.67 \\
\hline
\end{tabular}

- Diastolic dysfunction was objectified in $68 \%$ of patients, of which $54 \%$ of patients had diastolic dysfunction type 1 (28 cases), $8 \%$ had diastolic dysfunction type 2 (4 cases) and $4 \%$ had diastolic dysfunction type 3 (2 cases).
- The dilation of the left atrium was found in $8 \%$ of the patients, while $4 \%$ of the patients had an $\mathrm{LVH}$ (2 cases).

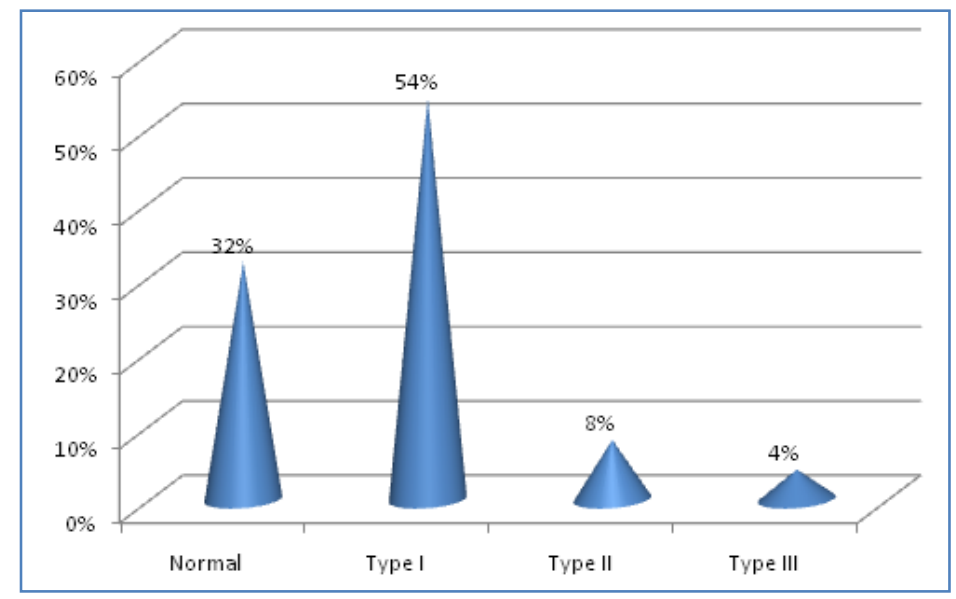

Diagram-7: Distribution of patients according to the mitral profile

- The filling pressures of the left ventricle were high in $10 \%$ of the patients in this study.

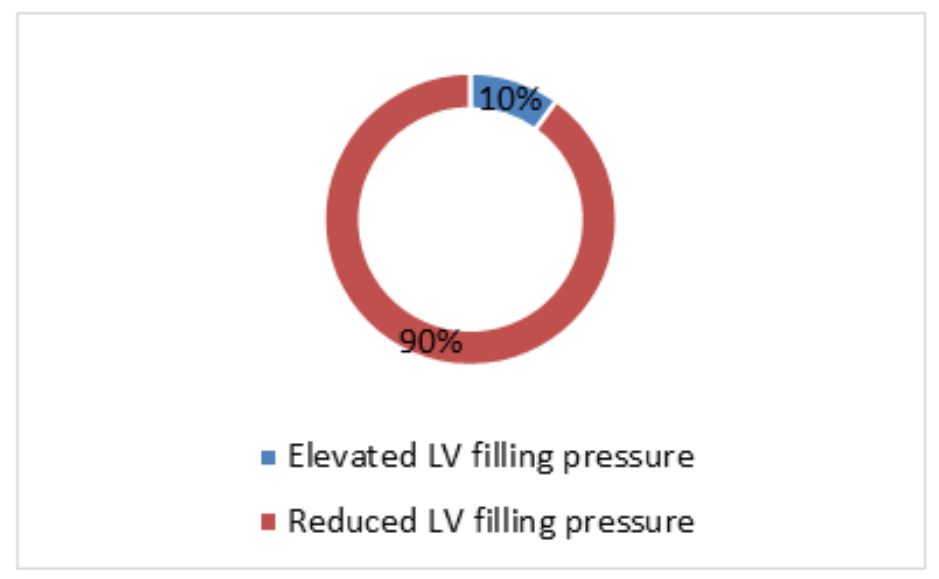

Diagram-8: Distribution according to the filling pressures of the left ventricle 
Table-IV: Risk factor found in patients with normal diastolic function and patients with diastolic dysfunction

\begin{tabular}{|c|c|c|c|c|}
\hline Risk factors & Diastolic dysfunction & normal diastolic function & P & Correlation coefficient (r) \\
\hline Age & 62.26 ans & 61.5 ans & 0.803 & -0.036 \\
HBP & $16 \%$ & $10 \%$ & 0.57 & -0.082 \\
Diabetes & $30 \%$ & $16 \%$ & 0.704 & -0.055 \\
Obesity & $28 \%$ & $14 \%$ & 0.86 & -0.024 \\
Dyslipidemia & $14 \%$ & $0 \%$ & 0.052 & +0.27 \\
Coronary inheritance & $0 \%$ & $0 \%$ & NS & NS \\
Smoking & $38 \%$ & $16 \%$ & 0.704 & 0.055 \\
\hline
\end{tabular}

- The risk factors that represent a correlation with diastolic dysfunction is dyslipidemia with a correlation coefficient of 0.27 .

Table-V: Other factors found in patients with normal diastolic function and patients with diastolic dysfunction

\begin{tabular}{|c|c|c|c|c|}
\hline other factor & $\begin{array}{c}\text { Diastolic } \\
\text { dysfunction }\end{array}$ & $\begin{array}{c}\text { normal diastolic } \\
\text { function }\end{array}$ & $\mathbf{P}$ & $\begin{array}{c}\text { Correlation coefficient } \\
\text { (r) }\end{array}$ \\
\hline Heart rate & 78.97 & 85.81 & 0.29 & 0.153 \\
Systolic pressure & 123.67 & 129.87 & 0.21 & 0.17 \\
Diastolic pressure & 70.73 & 73.87 & 0.33 & 0.14 \\
Reperfusion & $29 \%$ & $62 \%$ & 0.44 & -1.26 \\
Numbe rof affected & 2.55 & 1.75 & 0.048 & 0.363 \\
arteries & 29.5 & 18.31 & 0.064 & 0.264 \\
Admission(h) & $50 \%$ & $68 \%$ & 0.221 & 0.176 \\
EKGTopography(ASA) & & & & \\
\hline
\end{tabular}

- The other factors that represent a correlation with diastolic dysfunction are: the number of arteries affected at the coronary angiography, and the time of admission.
- The ejection fraction was more than $50 \%$ in $30 \%$ of the cases and less than $50 \%$ in $70 \%$ of the cases.

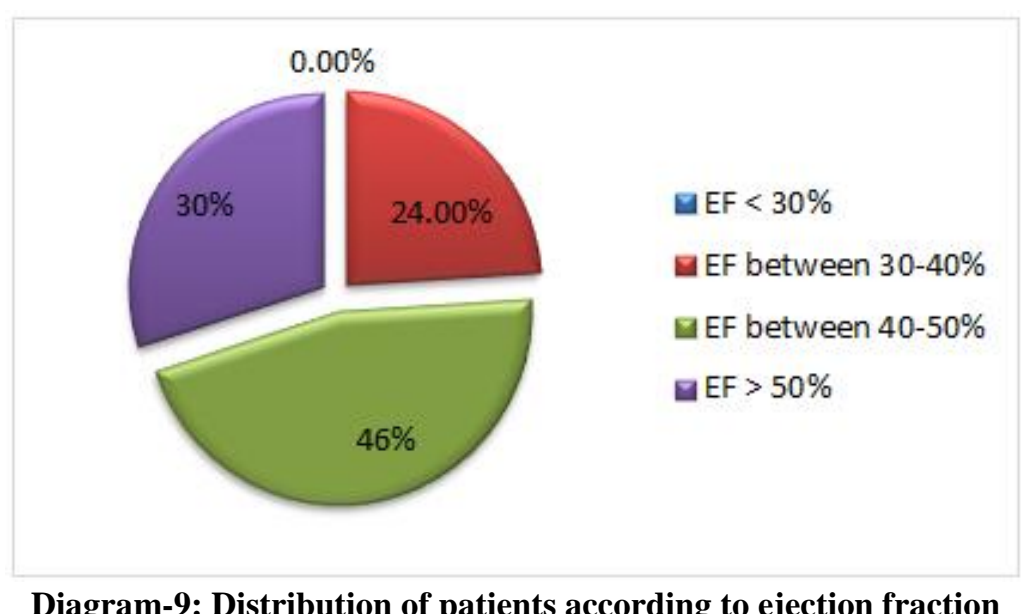

Diagram-9: Distribution of patients according to ejection fraction

- Contractility disorders were present in $82 \%$ of patients.

Table-VI: Analysis of contractility

\begin{tabular}{|c|c|c|}
\hline Contractility & cases & Percentage (\%) \\
\hline Normal & 9 & 18 \\
\hline Akinesia & 4 & 8 \\
\hline Hypokinesia & 27 & 54 \\
\hline Both (hypo and akinesia) & 10 & 20 \\
\hline Dyskinesia & 0 & 0 \\
\hline
\end{tabular}




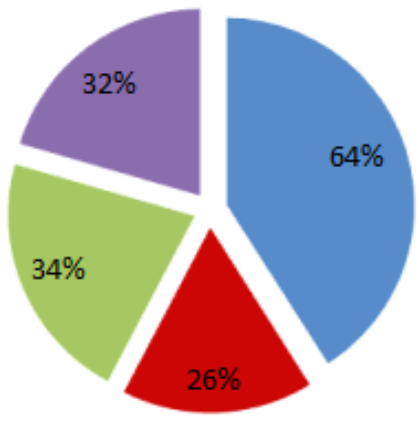

Antero septal

- Anterior wall

anferieur wall

Diagram-10: Representation of the sectoral impact of myocardial kinetics

- The coronary angiography was done in $58 \%$ of the cases (29 patients), objectifying bi-trunk lesions in $20 \%$ of the patients. It was normal in $6 \%$ of cases.

Table-VII: Angiographic aspects

\begin{tabular}{|c|c|c|}
\hline Coronary artery disease & cases & Percentage (\%) \\
\hline Mono-trunk & 8 & 16 \\
\hline Bi-trunk & 10 & 20 \\
\hline Tri-trunk & 8 & 16 \\
\hline No coronary damage & 3 & 6 \\
\hline
\end{tabular}

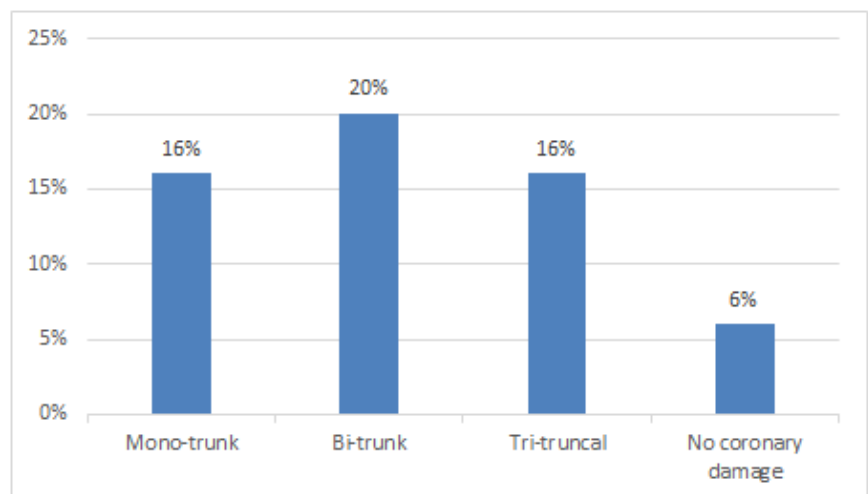

Diagram-11: Distribution by number of arteries affected by coronary angiography

- The affected arteries were distributed as follows:

Table-VIII: Distribution according to the site of the lesion

\begin{tabular}{|l|l|}
\hline Artery affected & Number of cases \\
\hline Left main & 0 \\
\hline \multirow{3}{*}{ Interventricular artery } & Proximal $: 16$ \\
\cline { 2 - 2 } & Mid $: 6$ \\
\cline { 2 - 2 } Circumflex & Distal $: 4$ \\
\hline \multirow{2}{*}{ Right coronary } & $\mathrm{P}: 7$ \\
\cline { 2 - 2 } & $\mathrm{M}: 7$ \\
\cline { 2 - 2 } & $\mathrm{D}: 3$ \\
\hline \multirow{4}{*}{ Collateral } & $1^{\text {st }}$ segment $: 11$ \\
\cline { 2 - 2 } & $2^{\text {nd }}$ segment $: 9$ \\
\cline { 2 - 2 } & $3^{\text {rd }}$ segment $: 1$ \\
\hline & Marginal $: 1$ \\
\cline { 2 - 2 } & Diagonal $: 1$ \\
\hline
\end{tabular}




\section{Therapeutic aspects:}

- The patients received drug treatments, detailed in this table:

Table-IX: Drug treatments

\begin{tabular}{|l|c|c|}
\hline & Cases & Percentage (\%) \\
\hline Aspirin & 50 & 100 \\
\hline Clopidogrel & 49 & 98 \\
\hline Statins & 47 & 94 \\
\hline Nitro derivatives & 4 & 8 \\
\hline calcium blockers & 1 & 2 \\
\hline CEI & 18 & 36 \\
\hline Diuretic & 7 & 14 \\
\hline Beta-blockers & 20 & 40 \\
\hline Unfractionated heparin & 2 & 4 \\
\hline LMWH & 48 & 96 \\
\hline Insulin & 19 & 38 \\
\hline
\end{tabular}

- Angioplasty was performed in $28 \%$ of the cases (14 patients).

- Thrombolysis was performed in $6 \%$ of cases (3 patients).

\section{Hospital complications}

- Rhythm disorder in one case.

- Three patients presented a 2nd degree atrioventricular block (conduction disorder).

- $\quad$ Four patients developed left heart failure (8\%).

\section{DISCUSSION}

The average age in this study was $62 \pm 9.95$ years with extremes of 40 and 85 years. In the prospective Ennezat study [13], the average age of the patients was $62 \pm 14$ years. According to the Poulsen study [14], which is a prospective study of 63 patients, the average age was $61 \pm 10$ years with extremes of 40 and 75 years. In the Fujii study [15], the average age was 53 with extremes of 25 and 65 . Males accounted for $66 \%$ in this study. According to Ennezat [13], 69\% of the patients were male.

Data from the literature have shown that smoking is one of the main cardiovascular risk factors [16]. It remains the most significant modifiable cardiovascular risk factor in the study population $(54 \%)$. Smoking was objectified in $60 \%$ of cases in
Ennezat [13], 48\% of cases in Jacob [17], 81\% of cases in the Poulsen study [14], and $23 \%$ of cases according to Graham [18].

Extensive studies have been conducted indicating that diabetes is associated with a cardiomyopathic process and affects diastolic function, this dysfunction can occur sooner or later during diabetes [19]. In this series, diabetes represented $46 \%$ of the patients. According to Graham [18], 56\% of the study population was diabetic and $28 \%$ according to Ennezat [13].

Several echocardiographic and Doppler studies have confirmed the existence in non-hypertensive obese patients of an increase in isovolumic relaxation time and an alteration of the parameters of ventricular filling, reflecting a decrease in compliance [20,21].

This can be explained by a structural adaptation of the heart ( $\mathrm{HVG}$ and dilations of the ventricles and atria) and to functional anomalies essentially a diastolic dysfunction with conserved EF which will progress to systolic dysfunction [22]. Hypertension is a very common condition [23]. Elevated LV filling pressures have been noted in patients with a history of hypertension after a heart attack [24].

Table-X: Summary table of data from the literature and data from this study

\begin{tabular}{|c|c|c|c|c|c|c|}
\hline Authors & Ennezat[13] & Poulsen[14] & Jacob[17] & Graham[18] & Nakajima[25] & This study \\
\hline Smoking (\%) & 60 & 81 & 48 & 11 & - & 54 \\
\hline Diabetes (\%) & 28 & 8 & 27 & 56 & - & 46 \\
\hline Obesity (\%) & - & - & 30 & - & - & 42 \\
\hline HBP (\%) & 57 & 16 & 25 & 57 & - & 26 \\
\hline Dyslipidemia (\%) & 53 & - & - & 42 & 74 & 24 \\
\hline
\end{tabular}

In this study, chest pain was present in $92 \%$, it was atypical in $13 \%$ of patients. In the Nakajima study [25], chest pain without dyspnea was present in $14 \%$ of patients; dyspnea without chest pain was reported in
$27 \%$ of patients while chest pain and dyspnea were objectified in $14 \%$ of patients. 
In this series, the rhythm was sinus in all patients, an over-shift of the ST segment in $68 \%$ of the cases, an under-shift of the ST segment in $30 \%$ of the cases and a negative $\mathrm{T}$ wave in $22 \%$ of the cases. According to Rogério [7], 91.4\% of the patients had a sinus rhythm, an over-shift of the ST segment in $7 \%$ of the cases and a negative $\mathrm{T}$ wave in $14.3 \%$ of the cases. An over-shift of the ST segment was reported in $63 \%$ of cases according to Ennezat [13] and in $48 \%$ of cases according to Graham [18].

In this study, diastolic dysfunction was objectified in $68 \%$ of patients, including $54 \%$ of cases with diastolic dysfunction type I (relaxation disorders), $8 \%$ of cases with dysfunction type II (pseudo-normal) and $4 \%$ of cases with type III dysfunction (restrictive). According to Chenzbraun [26], which is a comparative study between 38 patients with myocardial infarction and 15 healthy patients. Among coronary patients, 50\% had diastolic dysfunction, $37 \%$ with relaxation disorders and $13 \%$ with a restrictive profile. According to Poulsen [14], 62\% of the population studied had a diastolic dysfunction, including $37 \%$ with relaxation disorders and $25 \%$ with an E-wave deceleration time $<140 \mathrm{~ms}$ which can mean pseudo-normal or restrictive filling.

A restrictive fill model is an important predictor of an adverse outcome after MI, regardless of LVEF, size of LV, and severity of heart failure [12].
We found a significant correlation between diastolic dysfunction and dyslipidemia $(\mathrm{p}=0.052)$. Dyslipidemia is an important modifiable risk factor for cardiovascular disease [27], and a determinant of severity in acute coronaries [28]. We did not find a significant correlation between diastolic dysfunction and diabetes, hypertension or obesity. Joining Chenzbraun [26], no correlation was found between the filling profile of LV and diabetes or hypertension. Gulel et al did not report any significant difference between left atrial diastolic function between obese and nonobese subjects [29]. In contrast, other studies have found the prevalence of LV diastolic dysfunction to be high in diabetic and hypertensive patients [30]. Bauters et al reported that hyperglycemia on admission predicted LV reshaping after a previous anterior myocardial infarction in non-diabetic patients [31]. We found a significant correlation between diastolic dysfunction and the number of arteries affected $(\mathrm{p}=$ 0.048), which joins a comparative study between patients with large infarctions and those with small infarctions. Patients with large infarctions had a restrictive filling [32-34]. Another study found a correlation between infarction size and diastolic function, larger infarction size was associated with reduced early filling rate [35].

The E / e ratio has been well validated to assess LV filling pressures [36, 37]. In this study, 10\% of this population had high left ventricle filling pressures.

Table-XII: comparison according to LVFP

\begin{tabular}{|c|c|c|c|c|}
\hline Authors & Ennezat[13] & Graham[18] & Chenzbraun [26] & Our study \\
\hline High LVFP (\%) & 16.3 & 29 & 13 & 10 \\
\hline
\end{tabular}

Systolic dysfunction was objectified in $70 \%$ of this population, with an average of $45.48 \pm 10 \%$, the ejection fraction was less than $40 \%$ in $24 \%$ of cases, while $\mathrm{EF} \leq 40 \%$ in $29 \%$

Only coronary angiography, to assess the number and location of hemodynamically significant stenosis. In our series, all patients received aspirin, $98 \%$ clopidogrel, $94 \%$ statins, $40 \%$ beta-blockers and $36 \%$ ACE inhibitors. Long-term treatment with trandolapril in patients with reduced left ventricular function rapidly after myocardial infarction significantly reduced the risk of overall mortality, cardiovascular mortality, sudden death and the development of severe heart failure.

This mortality was reduced in a randomized study by enrolling 25 percent of consecutive patients to encourage selective use of IEC after a myocardial infarction [38].

Angioplasty was performed in $28 \%$ of cases while thrombolysis was performed in $6 \%$ of cases. In the Graham study [18], 16\% of patients underwent thrombolysis. $74 \%$ patients underwent percutaneous coronary intervention with stent and $7 \%$ bypass surgery [13].

\section{CONCLUSION}

Acute coronary syndrome remains a major public health issue in Morocco, given the still increasing incidence despite progress in treatment and prevention. The evaluation of diastolic function during hospitalization for myocardial infarction should be systematic since it can provide an additional stratification of the prognostic risk [11]. As a result, new public health strategies should be developed to facilitate rapid access to acute care, as well as an education information and communication strategy, particularly in patients at risk of coronary artery disease, in order to shorten the time taken for the management of coronary patients

\section{REFERENCES}

1. Du LJ, Dong PS, Jia JJ, Fan XM, Yang XM, Wang SX, Yang XS, Li ZJ, Wang HL. Association between left ventricular end-diastolic pressure and coronary artery disease as well as its extent and 
severity. International journal of clinical and experimental medicine. 2015;8(10):18673.

2. Nishimura RA, Tajik AJ. Evaluation of diastolic filling of left ventricle in health and disease: Doppler echocardiography is the clinician's Rosetta Stone. Journal of the American College of Cardiology. 1997 Jul 1;30(1):8-18.

3. Humphrey LS, Topol EJ, Rosenfeld GI, Borkon AM, Baumgartner WA, Gardner TJ, Maruschak G, Weiss JL. Immediate enhancement of left ventricular relaxation by coronary artery bypass grafting: intraoperative assessment. Circulation. 1988 Apr;77(4):886-96.

4. De Bruyne B, Bronzwaer JG, Heyndrickx GR, Paulus WJ. Comparative effects of ischemia and hypoxemia on left ventricular systolic and diastolic function in humans. Circulation. 1993 Aug;88(2):461-71.

5. Oh JK, Ding ZP, Gersh BJ, Bailey KR, Tajik AJ. Restrictive left ventricular diastolic filling identifies patients with heart failure after acute myocardial infarction. Journal of the American Society of Echocardiography. 1992 Sep 1;5(5):497503.

6. Mahmarian JJ, Pratt CM. Silent myocardial ischemia in patients with coronary artery disease. Possible links with diastolic left ventricular dysfunction. Circulation. 1990 Feb;81(2 Suppl):III33-40.

7. Teixeira R, Lourenço C, Baptista R, Jorge E, Mendes P, Saraiva F, Monteiro S, Gonçalves F, Monteiro P, Ferreira MJ, Freitas M. Left ventricular end diastolic pressure and acute coronary syndromes. Arq Bras Cardiol. 2011 Aug 1;97(2):100-10.

8. Hogg K, Swedberg K, McMurray J. Heart failure with preserved left ventricular systolic function: epidemiology, clinical characteristics, and prognosis. Journal of the American College of Cardiology. 2004 Feb 4;43(3):317-27.

9. Wijns W, Serruys PW, Slager CJ, Grimm J, Krayenbuehl HP, Hugenholtz PG, Hess OM. Effect of coronary occlusion during percutaneous transluminal angioplasty in humans on left ventricular chamber stiffness and regional diastolic pressure-radius relations. Journal of the American College of Cardiology. 1986 Mar 1;7(3):455-63.

10. Kane GC, Karon BL, Mahoney DW, Redfield MM, Roger VL, Burnett JC, Jacobsen SJ, Rodeheffer RJ. Progression of left ventricular diastolic dysfunction and risk of heart failure. Jama. 2011 Aug 24;306(8):856-63.

11. Khumri TM, Reid KJ, Kosiborod M, Spertus JA, Main ML. Usefulness of left ventricular diastolic dysfunction as a predictor of one-year rehospitalization in survivors of acute myocardial infarction. The American journal of cardiology. 2009 Jan 1;103(1):17-21.

12. Dr Gillian Whalley, PhD, Independent Prognostic Importance of a Restrictive Left Ventricular Filling
Pattern after Myocardial Infarction An Individual Patient Meta-Analysis: Meta-Analysis Research Group in Echocardiography Acute Myocardial Infarction Circulation. 2008;117:2591-2598.

13. Ennezat V. Marjorie Richardson-Lobbedez, Sylvestre Mare'chaux1, Christophe Bauters, Julie Darchis, Jean Luc Auffray and al. Prognostic importance of tissue Doppler-derived diastolic function in patients presenting with acute coronary syndrome: a bedside echocardiographic study European Journal of Echocardiogr aphy. 2008:9;594- 598.

14. Poulsen SH, Jensen SE, Gøtzsche O, Egstrup K. Evaluation and prognostic significance of left ventricular diastolic function assessed by Doppler echocardiography in the early phase of a first acute myocardial infarction. European heart journal. 1997 Dec 1;18(12):1882-9.

15. Fujii J, Yazaki Y, Sawada H, Aizawa T, Watanabe $\mathrm{H}$, Kato K. Noninvasive assessment of left and right ventricular filling in myocardial infarction with a two-dimensional Doppler echocardiography method. Journal of the American College of Cardiology. 1985 May 1;5(5):1155-60.

16. Ezzati M, Henley SJ, Thun MJ, Lopez AD. Role of smoking in global and regional cardiovascular mortality. Circulation. 2005 Jul 26;112(4):489-97.

17. Møller JE, Egstrup K, Køber L, Poulsen SH, Nyvad O, Torp-Pedersen C. Prognostic importance of systolic and diastolic function after acute myocardial infarction. American heart journal. 2003 Jan 1;145(1):147-53.

18. Hillis GS, Møller JE, Pellikka PA, Gersh BJ, Wright RS, Ommen SR, Reeder GS, Oh JK. Noninvasive estimation of left ventricular filling pressure by E/e' is a powerful predictor of survival after acute myocardial infarction. Journal of the American College of Cardiology. 2004 Feb 4;43(3):360-7.

19. Stone PH, Muller JE, Hartwell T, York BJ, Rutherford JD, Parker CB, Turi ZG, Strauss HW, Willerson JT, Robertson T, Braunwald E. The effect of diabetes mellitus on prognosis and serial left ventricular function after acute myocardial infarction: contribution of both coronary disease and diastolic left ventricular dysfunction to the adverse prognosis. Journal of the American College of Cardiology. 1989 Jul 1;14(1):49-57.

20. Roncalli J, Pathak A. Obésité et insuffisance cardio-vasculaire. Mt cardio. 2007; 3 (3): 178-86.

21. Martin A. Alpert, JadOmran, Brian P. Bostick. Effects of Obesity on Cardiovascular Hemodynamics, Cardiac Morphology, and Ventricular Function. CurrObes Rep.2016.

22. Russo C, Jin Z, Homma S, Rundek T, Elkind MS, Sacco RL, Di Tullio MR. Effect of obesity and overweight on left ventricular diastolic function: a community-based study in an elderly cohort. Journal of the American College of Cardiology. 2011 Mar 22;57(12):1368-74. 
23. Maurer MS, King DL, Rumbarger LE, Packer M, Burkhoff D. Left heart failure with a normal ejection fraction: identification of different pathophysiologic mechanisms. Journal of cardiac failure. 2005 Apr 1;11(3):177-87.

24. Nagueh SF, Rao L, Soto J, Middleton KJ, Khoury DS. Haemodynamic insights into the effects of ischaemia and cycle length on tissue Dopplerderived mitral annulus diastolic velocities. Clinical science. 2004 Feb 1;106(2):147-54.

25. Nakajima Y, Kane GC, McCully RB, Ommen SR, Pellikka PA. Left ventricular diastolic filling pressures during dobutamine stress echocardiography: relationship to symptoms and ischemia. Journal of the American Society of Echocardiography. 2009 Aug 1;22(8):947-53.

26. Chenzbraun A, Keren A, Stern S. Doppler echocardiographic patterns of left ventricular filling in patients early after acute myocardial infarction. The American journal of cardiology. 1992 Sep 15;70(7):711-4.

27. MD, PhDRobert J. Petrella1PhDElizabethMerikle2BScJaredJones 1 Prevalence and treatment of dyslipidemia in canadian primary care: A retrospective cohort analysis Clinical Therapeutics. 2007:29(4);742750

28. Rafaela Andrade Penalva; Marçal de Oliveira Huoya; Luis Cláudio Lemos Correia; Gilson Soares Feitosa; Ana Marice Teixeira Ladeia Perfil lipídico e intensidade de doença aterosclerótica na síndrome coronariana aguda Arq. Bras. Cardiol. 2008:90; 1 .

29. Gulel O, Yuksel S, Soylu K, Kaplan O, Yilmaz O, Kahraman H, Sahin M. Evaluation of left atrial functions by color tissue Doppler imaging in adults with body mass indexes $\geq 30 \mathrm{~kg} / \mathrm{m} 2$ versus those $<$ $30 \mathrm{~kg} / \mathrm{m}$ 2. The international journal of cardiovascular imaging. 2009 Apr 1;25(4):371-7.

30. Poulsen MK, Henriksen JE, Dahl J, Johansen A, Gerke O, Vach W, Haghfelt T, H ilund-Carlsen PF, Beck-Nielsen H. Left ventricular diastolic function in type 2 diabetes mellitus: prevalence and association with myocardial and vascular disease. Circulation: Cardiovascular Imaging. 2010 Jan;3(1):24-31.

31. Bauters C, Ennezat PV, Tricot O, Lauwerier B, Lallemant R, Saadouni H, Quandalle P, Jaboureck
O, Lamblin N, Le Tourneau T. Stress hyperglycaemia is an independent predictor of left ventricular remodelling after first anterior myocardial infarction in non-diabetic patients. European heart journal. 2007 Mar 1;28(5):546-52.

32. Pipilis A, Meyer TE, Ormerod O, Flather M, Sleight P. Early and late changes in left ventricular filling after acute myocardial infarction and the effect of infarct size. American Journal of Cardiology. 1992 Dec 1;70(18):1397-401.

33. Fukuta H, Ohte N, Wakami K, Goto T, Tani T, Kimura G. Prognostic value of left ventricular diastolic dysfunction in patients undergoing cardiac catheterization for coronary artery disease. Cardiology research and practice. 2012;2012.

34. Strauer BE, Bolte HD, Heimburg P, Riecker G. Coronary disease. II. Analysis of diastolic pressurevolume correlations and left ventricular elasticity in 110 patients. Zeitschrift fur Kardiologie. 1975 Apr;64(4):311-22.

35. Johannessen KA, Cerqueira MD, Stratton JR. Influence of myocardial infarction size on radionuclide and Doppler echocardiographic measurements of diastolic function. The American journal of cardiology. 1990 Mar 15;65(11):692-7.

36. Ommen SR, Nishimura RA, Appleton CP, Miller FA, Oh JK, Redfield MM, Tajik AJ. Clinical utility of Doppler echocardiography and tissue Doppler imaging in the estimation of left ventricular filling pressures: a comparative simultaneous Dopplercatheterization study. Circulation. 2000 Oct 10;102(15):1788-94.

37. Hillis GS, Møller JE, Pellikka PA, Gersh BJ, Wright RS, Ommen SR, Reeder GS, Oh JK. Noninvasive estimation of left ventricular filling pressure by $E / \mathrm{e}^{\prime}$ is a powerful predictor of survival after acute myocardial infarction. Journal of the American College of Cardiology. 2004 Feb 4;43(3):360-7.

38. Køber L, Torp-Pedersen C, Carlsen JE, Bagger H, Eliasen P, Lyngborg K, Videbæk J, Cole DS, Auclert L, Pauly NC, Aliot E. A clinical trial of the angiotensin-converting-enzyme inhibitor trandolapril in patients with left ventricular dysfunction after myocardial infarction. New England Journal of Medicine. 1995 Dec 21;333(25):1670-6. 